\title{
Pseudoxanthomonas sacheonensis sp. nov., isolated from BTEX-contaminated soil in Korea, transfer of Stenotrophomonas dokdonensis Yoon et al. 2006 to the genus Pseudoxanthomonas as Pseudoxanthomonas dokdonensis comb. nov. and emended description of the genus Pseudoxanthomonas
}

\section{Correspondence Che Ok Jeon cojeon@cau.ac.kr}

\author{
Dae Sung Lee, ${ }^{1} \dagger$ Seung Hyun Ryu, ${ }^{2} \dagger$ Hyun Wook Hwang, ${ }^{1}$ \\ Young-Ju Kim, ${ }^{1}$ Minjeong Park, ${ }^{2}$ Jung Ro Lee, ${ }^{2}$ Sang-Suk Lee ${ }^{3}$ \\ and Che Ok Jeon ${ }^{4}$ \\ ${ }^{1}$ Department of Environmental Engineering, Kyungpook National University, Sankyuk-dong, Buk-gu, \\ Daegu 702-701, Republic of Korea \\ ${ }^{2}$ Division of Applied Life Science (BK21 program), EB-NCRC, Gyeongsang National University, \\ Jinju 660-701, Republic of Korea \\ ${ }^{3}$ Department of Animal Science and Technology, Sunchon National University, Sunchon 540-742, \\ Republic of Korea \\ ${ }^{4}$ Department of Life Science, Chung-Ang University, Seoul 156-756, Republic of Korea
}

A Gram-negative, strictly aerobic, rod-shaped bacterium, designated strain BD-c54 ${ }^{\top}$, was isolated from BTEX (benzene, toluene, ethylbenzene and xylenes)-contaminated soil in Sacheon, Korea. Growth of strain BD-c5 $4^{\top}$ was observed at $15-35{ }^{\circ} \mathrm{C}$ (optimum $25-30{ }^{\circ} \mathrm{C}$ ) and $\mathrm{pH} 6.0-$ 9.5 (optimum pH 7.0-8.0). The predominant fatty acids were iso- $\mathrm{C}_{15: 0}$, iso- $\mathrm{C}_{17: 1} \omega 9 \mathrm{c}$, iso- $\mathrm{C}_{11: 0}$ $3-\mathrm{OH}$, iso- $\mathrm{C}_{16: 0}$, iso- $\mathrm{C}_{11: 0}$ and iso- $\mathrm{C}_{17: 0}$. The strain contained large amounts of phosphatidylethanolamine, phosphatidylglycerol and diphosphatidylglycerol and a small amount of an unknown amino-group-containing polar lipid as polar lipids. The major quinone was ubiquinone-8 $(\mathrm{Q}-8)$ and the $\mathrm{G}+\mathrm{C}$ content of the genomic DNA was $67.5 \mathrm{~mol} \%$. A phylogenetic analysis based on $16 \mathrm{~S}$ rRNA gene sequences showed that strain BD-c54 ${ }^{\top}$ formed a tight phylogenetic lineage with Pseudoxanthomonas yeongjuensis GR12-1 ${ }^{\top}$ within the genus Pseudoxanthomonas and was most closely related to $P$. yeongjuensis GR12-1 ${ }^{\top}$ and [Stenotrophomonas] dokdonensis DS-16 ${ }^{\top}$, with 98.3 and $96.6 \% 16 \mathrm{~S}$ rRNA gene sequence similarity, respectively. The DNA-DNA relatedness between strain $\mathrm{BD}-\mathrm{c} 54^{\top}$ and $P$. yeongjuensis GR12-1 ${ }^{\top}$ was $24.5 \%$. On the basis of chemotaxonomic data and molecular properties, strain BDc54 ${ }^{\top}$ represents a novel species within the genus Pseudoxanthomonas, for which the name Pseudoxanthomonas sacheonensis sp. nov. is proposed. The type strain is BD-c54 ${ }^{\top}(=\mathrm{KCTC}$ $22080^{\top}=$ DSM $19373^{\top}$ ). In addition, the transfer of Stenotrophomonas dokdonensis to Pseudoxanthomonas as Pseudoxanthomonas dokdonensis comb. nov. and an emended description of the genus Pseudoxanthomonas are proposed.
tThese authors contributed equally to this work.

Abbreviation: BTEX, benzene, toluene, ethylbenzene and xylenes.

The GenBank/EMBL/DDBJ accession number for the 16S rRNA gene sequence of strain $B D-c 54^{\top}$ is EF575564.

A transmission electron micrograph of cells of strain $B D-c 54^{\top}$ and results of TLC of its polar lipids are available as supplementary material with the online version of this paper.
The genus Pseudoxanthomonas Finkmann et al. 2000 belongs to the family Xanthomonadaceae in the order Xanthomonadales of the Gammaproteobacteria. This genus is closely related phylogenetically to the genera Xanthomonas, Xylella and Stenotrophomonas. These genera share the presence of branched-chain fatty acids and ubiquinone-8 (Q-8), but it has been reported that 
members of the genus Pseudoxanthomonas can be differentiated from members of the genera Xanthomonas and Stenotrophomonas by their ability to reduce nitrite but not nitrate to $\mathrm{N}_{2} \mathrm{O}$ and by the absence of the fatty acid iso$\mathrm{C}_{13: 0}$ 3-OH (Assih et al., 2002; Thierry et al., 2004). However, more recently, Pseudoxanthomonas kaohsiungensis (Chang et al., 2005) has been reported as being able to reduce nitrate and Pseudoxanthomonas spadix (Young et al., 2007) contains the fatty acid iso- $\mathrm{C}_{13: 0} 3-\mathrm{OH}$.

In the course of the screening of micro-organisms from contaminated soil samples, we isolated a novel bacterium, designated strain $\mathrm{BD}-\mathrm{c} 54^{\mathrm{T}}$, that represents a novel species of the genus Pseudoxanthomonas. Phylogenetic analysis based on $16 \mathrm{~S}$ rRNA gene sequences showed that the isolate is closely related to Pseudoxanthomonas yeongjuensis GR12-1 $1^{\mathrm{T}}$ and [Stenotrophomonas] dokdonensis DS-16 ${ }^{\mathrm{T}}$. Although [S.] dokdonensis DS- $16^{\mathrm{T}}$ can reduce nitrate, we found that it should be classified within the genus Pseudoxanthomonas on the basis of phylogenetic and phenotypic characteristics (for example, iso- $\mathrm{C}_{13: 0} 3-\mathrm{OH}$ was not detected).

Strain BD-c54 ${ }^{\mathrm{T}}$ was isolated from BTEX (benzene, toluene, ethylbenzene and xylenes)-contaminated soil in Sacheon, Republic of Korea. The soil sample was contaminated to a level of about $1 \mathrm{~g}$ total hydrocarbons $(\mathrm{kg} \text { soil })^{-1}$. The soil sample was serially diluted with $1 \%(\mathrm{w} / \mathrm{v})$ saline solution, spread on R2A agar (Difco) and incubated at $25{ }^{\circ} \mathrm{C}$ for 5 days. Subcultivation was done on R2A agar at $30{ }^{\circ} \mathrm{C}$ for 3 days. Although strain BD-c $54^{\mathrm{T}}$ was isolated from BTEXcontaminated soil, it did not grow on minimal agar medium (Stanier et al., 1966) containing BTEX as the sole carbon source, which means that the strain may not be a BTEX degrader.

Four type strains were used as reference strains for DNADNA hybridization and phenotypic characterization: [S.] dokdonensis KCTC $12543^{\mathrm{T}}$ was purchased from the Korean Collection of Type Cultures (Daejeon, Korea), P. yeongjuensis KACC $11580^{\mathrm{T}}$, Pseudoxanthomonas kalamensis KACC $12354^{\mathrm{T}}$ and Pseudoxanthomonas broegbernensis KACC $10898^{\mathrm{T}}$ were purchased from the Korean Agricultural Culture Collection (Suwon, Korea) and P. spadix IMMIB AFH-5 $5^{\mathrm{T}}$ was a gift from Dr A. F. Yassin (Young et al., 2007). Physiological characteristics of strain $\mathrm{BD}-\mathrm{c} 54^{\mathrm{T}}$ were examined by growing the isolate on $\mathrm{R} 2 \mathrm{~A}$ agar at different temperatures $\left(5-50{ }^{\circ} \mathrm{C}\right.$ at $5{ }^{\circ} \mathrm{C}$ intervals) and in $\mathrm{R} 2 \mathrm{~A}$ broth adjusted to different $\mathrm{pH}$ values ( $\mathrm{pH}$ 5.010.0 at $0.5 \mathrm{pH}$ unit intervals). R2A medium with different $\mathrm{pH}$ was prepared as described by Gomori (1955). Gram staining was performed using a bioMérieux Gram stain kit according to the instructions of the manufacturer. Oxidase activity was tested by oxidation of $1 \%(\mathrm{w} / \mathrm{v})$ tetramethyl $p$ phenylenediamine (Merck) and catalase activity was evaluated by the production of oxygen bubbles in $3 \%$ $(\mathrm{v} / \mathrm{v})$ aqueous hydrogen peroxide solution. Cell morphology and motility were studied using phase-contrast microscopy and transmission electron microscopy
(JEM-1010; JEOL) as described by Jeon et al. (2004). Hydrolysis of casein, gelatin, Tweens 20 and 80, aesculin, urea, tyrosine and starch was investigated on R2A agar after 5 days of incubation according to previously described methods (Lányí, 1987; Smibert \& Krieg, 1994). Nitrate reduction was assayed according to the method of Lányí (1987) and acid production from carbohydrates was tested as described by Leifson (1963). Additional enzyme activities and biochemical features were determined using API ZYM and API $20 \mathrm{NE}$ kits at $30{ }^{\circ} \mathrm{C}$ as recommended by the manufacturer (bioMérieux).

Growth of strain $\mathrm{BD}-\mathrm{c} 54^{\mathrm{T}}$ was observed at $15-35{ }^{\circ} \mathrm{C}$, with optimum growth at $25-30{ }^{\circ} \mathrm{C}$, and at $\mathrm{pH}$ 6.0-9.5, with optimum growth at $\mathrm{pH}$ 7.0-8.0. All cells that were observed were non-motile rods, $0.3-0.5 \mu \mathrm{m}$ wide and $0.8-1.6 \mu \mathrm{m}$ long at $30{ }^{\circ} \mathrm{C}$ on R2A agar (see Supplementary Fig. S1 in IJSEM Online). Cells of strain BD-c54 ${ }^{\mathrm{T}}$ stained Gram-negative and were oxidase- and catalase-positive. Anaerobic growth was not observed after 15 days at $30{ }^{\circ} \mathrm{C}$ on R2A agar. The strain did not reduce nitrate to nitrite. Other phenotypic features of strain BD-c54 ${ }^{\mathrm{T}}$, [S.] dokdonensis DS- $16^{\mathrm{T}}$ and other Pseudoxanthomonas type strains are presented in Table 1 and in the description of the novel species. Some features are in accordance with characteristics of members of the genus Pseudoxanthomonas, whereas others allow differentiation from closely related Pseudoxanthomonas species (Table 1).

For analysis of fatty acid methyl esters, cells of strain BD$\mathrm{c} 54^{\mathrm{T}}$ were harvested from agar plates after incubation for 3 days on tryptic soy agar (TSA; Difco) at $30{ }^{\circ} \mathrm{C}$. Analysis of fatty acid methyl esters was performed according to the instructions of the Microbial Identification System (MIDI Inc.). Analyses of polar lipids and isoprenoid quinones were carried out using the methods described by Komagata \& Suzuki (1987) and Batrakov et al. (1997), respectively. The DNA G $+\mathrm{C}$ content of strain $\mathrm{BD}-\mathrm{c} 54^{\mathrm{T}}$ was determined using HPLC with a reversed-phase column (GROM-SIL 100 ODS-2FE; GROM) according to the method of Tamaoka \& Komagata (1984). The major cellular fatty acids of strain $\mathrm{BD}-\mathrm{c} 54^{\mathrm{T}}$ were iso- $\mathrm{C}_{15: 0}(30.6 \%)$, iso$\mathrm{C}_{17: 1} \omega 9 c(12.3 \%)$, iso- $\mathrm{C}_{11: 0} 3-\mathrm{OH}(11.2 \%)$, iso- $\mathrm{C}_{16: 0}$ $(9.5 \%)$, iso- $\mathrm{C}_{11: 0}(9.4 \%)$ and iso- $\mathrm{C}_{17: 0}(8.6 \%)$, and $3-\mathrm{OH}$ fatty acids were the major hydroxylated components; this fatty acid profile is similar to those of Pseudoxanthomonas species and [S.] dokdonensis DS- $16^{\mathrm{T}}$ (Table 2). The fatty acid iso- $\mathrm{C}_{13: 0} 3-\mathrm{OH}$ was not detected from strain $\mathrm{BD}-\mathrm{c} 54^{\mathrm{T}}$, which is a general property of Pseudoxanthomonas species. The polar lipids of strain $\mathrm{BD}-\mathrm{c} 54^{\mathrm{T}}$ were dominated by large amounts of phosphatidylethanolamine, phosphatidylglycerol and diphosphatidylglycerol, but a small amount of an unknown amino-group-containing polar lipid (AL1) was also present (Supplementary Fig. S2). The major respiratory lipoquinone of strain $\mathrm{BD}-\mathrm{c} 54^{\mathrm{T}}$ was ubiquinone- 8 (Q-8). The $\mathrm{G}+\mathrm{C}$ content of strain $\mathrm{BD}-\mathrm{c} 54^{\mathrm{T}}$ was $67.5 \mathrm{~mol} \%$. The major fatty acids, major lipoquinone and $\mathrm{G}+\mathrm{C}$ content are in accordance with those of members of the genus Pseudoxanthomonas (Finkmann et al., 2000; 
Table 1. Phenotypic characteristics of strain $B D-c 54^{\top}$, [S.] dokdonensis $\mathrm{DS}-16^{\top}$ and type strains of some related Pseudoxanthomonas species

Strains: 1, strain BD-c54 ${ }^{\mathrm{T}}$ (data from this study); 2, P. yeongjuensis GR12-1 ${ }^{\mathrm{T}}$ (unless indicated, data from Yoo et al., 2007); 3, [S.] dokdonensis DS$16^{\mathrm{T}}$ (Yoon et al., 2006); 4, P. spadix IMMIB AFH-5 ${ }^{\mathrm{T}}$ (Young et al., 2007); 5, P. kalamensis JA40 ${ }^{\mathrm{T}}$ (Harada et al., 2006); 6, P. broegbernensis B1616/1 ${ }^{\mathrm{T}}$ (Finkmann et al., 2000). All strains were positive for catalase and aesculin hydrolysis and negative for starch hydrolysis, assimilation of D-mannitol and malate and growth at $42{ }^{\circ} \mathrm{C}$.

\begin{tabular}{|c|c|c|c|c|c|c|}
\hline Characteristic & 1 & 2 & 3 & 4 & 5 & 6 \\
\hline Urease $^{\star}$ & + & - & - & - & - & - \\
\hline Growth at $10{ }^{\circ} \mathrm{C}$ & - & + & + & - & + & + \\
\hline Nitrate reduction & - & - & + & - & - & - \\
\hline$\beta$-Galactosidase ${ }^{*}$ & + & + & - & - & - & + \\
\hline Gelatin & + & + & + & + & - & - \\
\hline Tween 80 & - & + & + & - & - & + \\
\hline Casein & + & + & + & + & - & - \\
\hline \multicolumn{7}{|l|}{ Assimilation of: ${ }^{*}$} \\
\hline D-Glucose & + & + & + & - & + & + \\
\hline L-Arabinose & - & - & - & - & + & + \\
\hline DNA G $+C$ content $(\mathrm{mol} \%)$ & 67.5 & 63.4 & 65.1 & 68.5 & 64.0 & 66.5 \\
\hline
\end{tabular}

*These results (and catalase activity, hydrolysis of aesculin and starch and assimilation of D-mannitol and malate) were obtained in this study with the strains indicated in the text.

Chen et al., 2002; Thierry et al., 2004; Chang et al., 2005; Yang et al., 2005; Harada et al., 2006; Weon et al., 2006; Yoo et al., 2007; Young et al., 2007). [S.] dokdonensis DS$16^{\mathrm{T}}$ has similar chemotaxonomic properties to members of the genus Pseudoxanthomonas, but it can reduce nitrate to nitrite, in contrast to previously reported general properties of Pseudoxanthomonas species (Harada et al., 2006; Thierry et al., 2004; Yoon et al., 2006; Young et al., 2007).

Sequencing and assembly of the 16S rRNA gene of strain $\mathrm{BD}-\mathrm{c} 54^{\mathrm{T}}$ were carried out as described previously (Lane, 1991). The resultant 16S rRNA gene sequence (1509 nt) was compared with available 16S rRNA gene sequences from GenBank using the BLAST program (http:// www.ncbi.nlm.nih.gov/BLAST/) to determine an approximate phylogenetic affiliation, and the sequence was aligned with those of closely related species using the CLUSTAL W software program (Thompson et al., 1994). Phylogenetic trees were constructed using three methods, the neighbour-joining (NJ), maximum-likelihood (ML) and maximum-parsimony (MP) algorithms; these methods are available in PHYLIP software, version 3.6 (Felsenstein, 2002). Sequence similarities between the novel strain and other related strains were computed using the FASTA3 program in EBI (http://www.ebi.ac.uk/fasta33/nucleotide. html). Bootstrap analysis was performed according to the algorithm of Kimura's two-parameter model (Kimura, 1980) of the NJ method in the PHYLIP package. DNA-DNA hybridization was carried out to evaluate the genomic DNA relatedness between strain $\mathrm{BD}-\mathrm{c} 54^{\mathrm{T}}$ and Pseudoxanthomonas yeongjuensis GR12-1 ${ }^{\mathrm{T}}$ using the fluorometric microplate method (Ezaki et al., 1989). Fluorometric data recorded after $30 \mathrm{~min}$ incubation were used for the calculation of a DNA-DNA hybridization value. The DNA relatedness value is the mean of five values.

Phylogenetic analysis based on 16S rRNA gene sequences indicated that strain $\mathrm{BD}-\mathrm{c} 54^{\mathrm{T}}$ formed a tight phylogenetic lineage with $P$. yeongjuensis GR12- $1^{\mathrm{T}}$ with a $100 \%$ bootstrap value within the genus Pseudoxanthomonas (Fig. 1). [S.] dokdonensis DS- $16^{\mathrm{T}}$ also formed a distinct phyletic lineage within the genus Pseudoxanthomonas. The overall tree topology of the NJ tree was supported by trees built using the ML and MP algorithms (Fig. 1). Comparative 16S rRNA gene sequence analysis showed that strain $\mathrm{BD}-\mathrm{c} 54^{\mathrm{T}}$ was most closely related to $P$. yeongjuensis GR12-1 ${ }^{\mathrm{T}}$ and $[S$.] dokdonensis DS-16 ${ }^{\mathrm{T}}$, with 98.3 and $96.6 \%$ 16S rRNA gene sequence similarity, respectively. The level of DNA-DNA relatedness between strain $\mathrm{BD}-\mathrm{c} 54^{\mathrm{T}}$ and $P$. yeongjuensis KACC $11580^{\mathrm{T}}$ was $24.5 \%$, which is clearly below the $70 \%$ threshold generally accepted for species delineation (Rosselló-Mora \& Amann, 2001; Wayne et al., 1987). 
Table 2. Cellular fatty acid compositions of strain BD-c54 $4^{\top},[S$.$] dokdonensis \mathrm{DS}-16^{\top}$ and type strains of some related Pseudoxanthomonas species grown on TSA

Strains: 1, strain BD-c54 (data from this study); 2, P. yeongjuensis GR12-1 ${ }^{\mathrm{T}}$ (Yoo et al., 2007); 3, [S.] dokdonensis DS-16 (Yoon et al., 2006); 4, P. spadix IMMIB AFH $-5^{\mathrm{T}}$ (Young et al., 2007); 5, P. kalamensis JA40 ${ }^{\mathrm{T}}$ (Harada et al., 2006); 6, P. broegbernensis B1616/1 ${ }^{\mathrm{T}}$ (Chen et al., 2002). Data are expressed as percentages of total fatty acids. -, Not detected.

\begin{tabular}{|c|c|c|c|c|c|c|}
\hline Fatty acid & 1 & 2 & 3 & 4 & 5 & 6 \\
\hline \multicolumn{7}{|l|}{ Saturated } \\
\hline$C_{10: 0}$ & 0.2 & - & - & - & 0.5 & - \\
\hline $\mathrm{C}_{14: 0}$ & 0.2 & - & - & 3.4 & 0.6 & 12.0 \\
\hline$C_{15: 0}$ & - & - & - & - & 0.2 & - \\
\hline$C_{16: 0}$ & 1.5 & 2.3 & 1.8 & 16.5 & 2.9 & 6.9 \\
\hline$C_{17: 0}$ & - & - & - & 0.2 & 0.4 & 1.5 \\
\hline $\mathrm{C}_{17: 0}$ cyclo & 0.2 & - & - & 2.8 & 0.2 & 1.1 \\
\hline \multicolumn{7}{|l|}{ Branched } \\
\hline iso- $\mathrm{C}_{10: 0}$ & 0.2 & - & - & - & - & - \\
\hline iso- $\mathrm{C}_{11: 0}$ & 9.4 & 5.5 & 5.6 & 1.3 & 6.9 & 1.4 \\
\hline iso- $\mathrm{C}_{12: 0}$ & 0.2 & - & - & - & - & - \\
\hline iso- $\mathrm{C}_{13: 0}$ & 0.4 & - & - & 0.5 & - & - \\
\hline anteiso- $\mathrm{C}_{13: 0}$ & - & - & - & 0.5 & - & - \\
\hline iso- $\mathrm{C}_{14: 0}$ & 1.6 & 1.4 & 2.1 & 1.0 & 0.6 & - \\
\hline iso- $\mathrm{C}_{15: 0}$ & 30.6 & 32.0 & 19.6 & 16.1 & 40.0 & 32.4 \\
\hline iso- $\mathrm{C}_{15: 1}$ AT5 & 1.3 & 1.0 & - & - & - & - \\
\hline anteiso- $\mathrm{C}_{15: 0}$ & - & 4.4 & 3.4 & 1.2 & 4.6 & 31.8 \\
\hline iso- $\mathrm{C}_{16: 0}$ & 9.5 & 13.3 & 27.6 & 6.4 & 6.9 & - \\
\hline iso- $\mathrm{C}_{17: 0}$ & 8.6 & 6.4 & - & 16.1 & 6.7 & - \\
\hline iso- $\mathrm{C}_{17: 1} \omega 7 c$ & - & - & - & - & 9.0 & 5.5 \\
\hline iso- $\mathrm{C}_{17: 1} \omega 8 c$ & - & - & - & 0.9 & - & - \\
\hline iso- $\mathrm{C}_{17: 1} \omega 9 c$ & 12.3 & 14.6 & 11.9 & 2.4 & - & - \\
\hline anteiso- $\mathrm{C}_{17: 0}$ & - & 1.5 & 1.5 & 23.6 & 1.8 & - \\
\hline anteiso- $\mathrm{C}_{17: 1}$ & 1.3 & - & - & - & - & - \\
\hline anteiso- $\mathrm{C}_{17: 1} \omega 9 c$ & 4.4 & - & - & - & - & - \\
\hline 10-Methyl C $17: 0$ & 0.3 & - & - & - & - & - \\
\hline iso- $\mathrm{C}_{18: 0}$ & 0.2 & - & - & - & - & - \\
\hline \multicolumn{7}{|l|}{ Unsaturated } \\
\hline $\mathrm{C}_{15: 1} \omega 9 c$ & - & - & - & - & 0.3 & - \\
\hline $\mathrm{C}_{16: 1} \omega 5 c$ & - & - & - & - & 1.2 & - \\
\hline $\mathrm{C}_{16: 1} \omega 7 c$ & - & - & - & - & - & 1.0 \\
\hline $\mathrm{C}_{16: 1} \omega 7 c$ alcohol & 2.4 & 1.6 & 1.0 & - & - & - \\
\hline $\mathrm{C}_{16: 1} \omega 9 c$ alcohol & - & - & - & - & 1.9 & - \\
\hline $\mathrm{C}_{16: 1} \omega 11 c$ & 0.4 & - & - & - & - & - \\
\hline $\mathrm{C}_{17: 1} \omega 8 \mathrm{c}$ & - & - & 0.9 & - & - & - \\
\hline $\mathrm{C}_{18: 1} \omega 7 \mathrm{c}$ & 0.4 & - & 1.5 & 0.4 & - & - \\
\hline $\mathrm{C}_{18: 1} \omega 9 \mathrm{c}$ & 0.1 & - & - & - & - & - \\
\hline \multicolumn{7}{|l|}{ Hydroxylated } \\
\hline $\mathrm{C}_{11: 0} 2-\mathrm{OH}$ & 0.3 & - & - & - & - & - \\
\hline $\mathrm{C}_{10: 0} 3-\mathrm{OH}$ & - & - & - & - & 0.2 & - \\
\hline $\mathrm{C}_{13: 0} 2-\mathrm{OH}$ & - & - & - & - & 0.1 & - \\
\hline iso- $\mathrm{C}_{11: 0} 3-\mathrm{OH}$ & 11.2 & 7.7 & 4.1 & 0.4 & 8.3 & 1.0 \\
\hline iso- $\mathrm{C}_{12: 0} 3-\mathrm{OH}$ & 0.3 & - & 2.8 & - & 0.4 & - \\
\hline iso- $\mathrm{C}_{13: 0} 3-\mathrm{OH}$ & - & - & - & 0.6 & - & - \\
\hline iso- $\mathrm{C}_{14: 0} 3-\mathrm{OH}$ & 0.3 & - & - & - & - & - \\
\hline \multicolumn{7}{|l|}{ Summed features* } \\
\hline 3 & 1.4 & 4.0 & 7.8 & 4.0 & - & - \\
\hline 4 & 0.6 & - & - & - & - & - \\
\hline
\end{tabular}

${ }^{\star}$ Summed features represent groups of two or three fatty acids that could not be separated by GLC with the MIDI system. Summed feature 3 contains $\mathrm{C}_{16: 1} \omega 7 c$ and/or iso- $\mathrm{C}_{15: 0} 2-\mathrm{OH}$. Summed feature 4 contains iso- $\mathrm{C}_{17: 1} \mathrm{I}$ and/or anteiso- $\mathrm{C}_{17: 1} \mathrm{~B}$. 


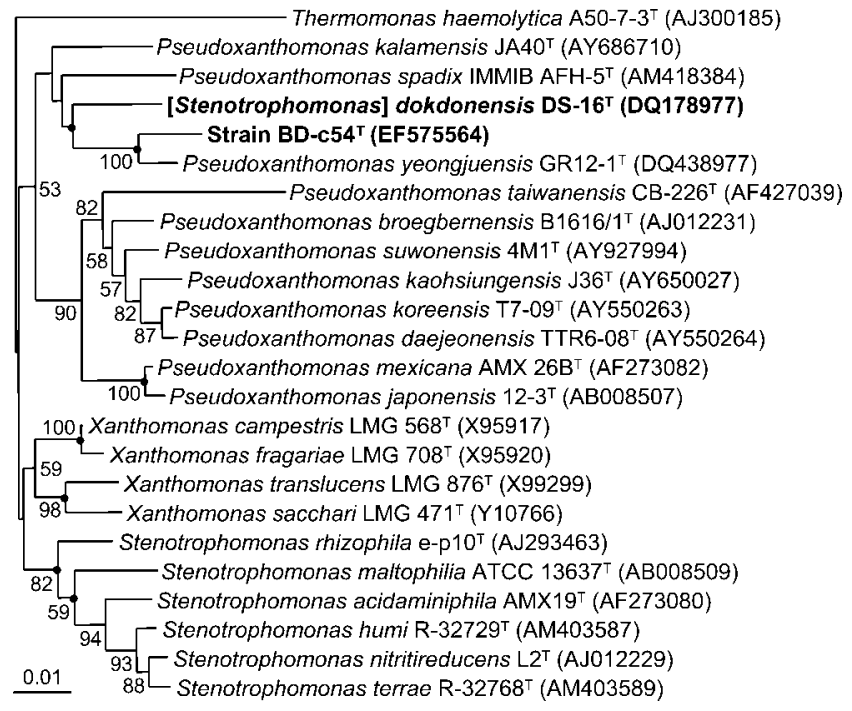

Fig. 1. NJ tree based on $16 \mathrm{~S}$ rRNA gene sequences showing the phylogenetic relationships of strain $\mathrm{BD}-\mathrm{c} 54^{\top}$, [S.] dokdonensis $\mathrm{DS}-16^{\top}$ and related taxa. Bootstrap values are shown as percentages of 1000 replicates when greater than $50 \%$. Filled circles indicate that the corresponding nodes were also recovered in trees generated with the ML and MP algorithms. Thermomonas haemolytica $\mathrm{A} 50-7-\mathrm{B}^{\top}$ was used as an outgroup. Bar, 0.01 changes per nucleotide position.

The chemotaxonomic and molecular characteristics described here show that strain $\mathrm{BD}-\mathrm{c} 54^{\mathrm{T}}$ and $[$ S.] dokdonensis DS- $16^{\mathrm{T}}$ are members of the genus Pseudoxanthomonas distinct from known species. We therefore propose the transfer of Stenotrophomonas dokdonensis to the genus Pseudoxanthomonas as Pseudoxanthomonas dokdonensis comb. nov. In addition, strain BD-c54 ${ }^{\mathrm{T}}$ represents a novel species in the genus Pseudoxanthomonas, for which the name Pseudoxanthomonas sacheonensis sp. nov. is proposed.

\section{Description of Pseudoxanthomonas sacheonensis sp. nov.}

Pseudoxanthomonas sacheonensis (sa.che.on.en'sis. N.L. fem. adj. sacheonensis pertaining to Sacheon, Korea, the location of the soil sample from which the type strain was isolated).

Colonies are yellow, opaque, circular and convex with entire margins after 3 days on R2A agar. Cells are strictly aerobic, Gram-negative, short, non-motile rods, 0.3$0.5 \mu \mathrm{m}$ wide and $0.8-1.6 \mu \mathrm{m}$ long. Optimal growth occurs at $25-30{ }^{\circ} \mathrm{C}$ and $\mathrm{pH} 7.0-8.0$. Catalase- and oxidasepositive. Nitrate is not reduced to nitrite. Hydrolyses aesculin, urea, tyrosine, casein and gelatin, but not Tweens 20 or 80 or starch. Produces acids from raffinose, lactose, L-arabinose, melibiose, D-fructose, D-mannose, D-mannitol, arbutin and salicin, but not from myo-inositol or Dgalactose. Positive for glucose fermentation, but negative for indole production and arginine dihydrolase activity. Positive for assimilation of D-glucose, D-mannose, $\mathrm{N}$ acetylglucosamine and maltose, but negative for assimilation of L-arabinose, D-mannitol, potassium gluconate, capric acid, adipic acid, malic acid, trisodium citrate and phenylacetic acid (API 20NE). Produces alkaline phosphatase, esterase (C4), esterase lipase (C8), leucine arylamidase, trypsin, $\alpha$-chymotrypsin, acid phosphatase, naphtholAS-BI-phosphohydrolase, $\beta$-galactosidase, $\alpha$-glucosidase, $\beta$-glucosidase and $N$-acetyl- $\beta$-glucosaminidase, but not $\alpha$ galactosidase or $\beta$-glucuronidase. Weak activities are observed for lipase (C14), valine arylamidase, cystine arylamidase, $\alpha$-mannosidase and $\alpha$-fucosidase. Contains large amounts of phosphatidylethanolamine, phosphatidylglycerol and diphosphatidylglycerol and a small amount of an unknown amino-group-containing polar lipid. The major isoprenoid quinone is $\mathrm{Q}-8$. The major cellular fatty acids are iso- $\mathrm{C}_{15: 0}$, iso- $\mathrm{C}_{17: 1} \omega 9 c$, iso- $\mathrm{C}_{11: 0} 3-\mathrm{OH}$, iso$\mathrm{C}_{16: 0}$, iso- $\mathrm{C}_{11: 0}$ and iso- $\mathrm{C}_{17: 0}$. The DNA G+C content of the type strain is $67.5 \mathrm{~mol} \%$ (HPLC).

The type strain is BD-c $54^{\mathrm{T}}\left(=\right.$ KCTC $\left.22080^{\mathrm{T}}=\mathrm{DSM} 19373^{\mathrm{T}}\right)$, isolated from BTEX-contaminated soil in Sacheon, Republic of Korea.

\section{Description of Pseudoxanthomonas dokdonensis (Yoon et al. 2006) comb. nov.}

Pseudoxanthomonas dokdonensis (dok.do.nen'sis. N.L. fem. adj. dokdonensis of Dokdo, from where the type strain was isolated).

Basonym: Stenotrophomonas dokdonensis Yoon et al. 2006.

The description is as given by Yoon et al. (2006). The type strain is DS $-16^{\mathrm{T}}\left(=\right.$ KCTC $12543^{\mathrm{T}}=$ CIP $\left.108839^{\mathrm{T}}\right)$.

\section{Emended description of the genus Pseudoxanthomonas Finkmann et al. 2000 emend. Thierry et al. 2004}

The description of the genus Pseudoxanthomonas is as given by Finkmann et al. (2000) and emended by Thierry et al. (2004) with the following changes. Type strains of all species except Pseudoxanthomonas kaohsiungensis and Pseudoxanthomonas dokdonensis have no nitrate reduction ability. The fatty acid iso- $\mathrm{C}_{13: 0} 3-\mathrm{OH}$ is detected only from Pseudoxanthomonas spadix and 3-OH fatty acids are the major hydroxylated components of the fatty acid profile.

\section{Acknowledgements}

These efforts were supported by grants from the MOST/KOSEF to the Environmental Biotechnology National Core Research Center (grant R15-2003-012-02002-0), from the BioGreen 21 Program (code 20070301034002), the Rural Development Administration and the ET Educational Innovation Project of the Ministry of Environment, Republic of Korea. S. H. R. and M. P. were supported by scholarships from the BK21 program, Ministry of Education and Human Resources Development, Republic of Korea. 


\section{References}

Assih, E. A., Ouattara, A. S., Thierry, S., Cayol, J.-L., Labat, M. \& Macarie, H. (2002). Stenotrophomonas acidaminiphila sp. nov., a strictly aerobic bacterium isolated from an upflow anaerobic sludge blanket (UASB) reactor. Int J Syst Evol Microbiol 52, 559-568.

Batrakov, S. G., Nikitin, D. I., Sheichenko, V. I. \& Ruzhitsky, A. O. (1997). Unusual lipid composition of the gram-negative, freshwater, stalked bacterium Caulobacter bacteroides NP-105. Biochim Biophys Acta 1347, 127-139.

Chang, J. S., Chou, C. L., Lin, G. H., Sheu, S. Y. \& Chen, W. M. (2005). Pseudoxanthomonas kaohsiungensis, sp. nov., a novel bacterium isolated from oil-polluted site produces extracellular surface activity. Syst Appl Microbiol 28, 137-144.

Chen, M.-Y., Tsay, S.-S., Chen, K.-Y., Shi, Y.-C., Lin, Y.-T. \& Lin, G.-H. (2002). Pseudoxanthomonas taiwanensis sp. nov., a novel thermophilic, $\mathrm{N}_{2} \mathrm{O}$-producing species isolated from hot springs. Int J Syst Evol Microbiol 52, 2155-2161.

Ezaki, T., Hashimoto, Y. \& Yabuuchi, E. (1989). Fluorometric deoxyribonucleic acid-deoxyribonucleic acid hybridization in microdilution wells as an alternative to membrane filter hybridization in which radioisotopes are used to determine genetic relatedness among bacterial strains. Int J Syst Bacteriol 39, 224-229.

Felsenstein, J. (2002). PHYLIP (phylogeny inference package) version 3.6a. Distributed by the author. Department of Genome Sciences, University of Washington, Seattle, USA.

Finkmann, W., Altendorf, K., Stackebrandt, E. \& Lipski, A. (2000). Characterization of $\mathrm{N}_{2} \mathrm{O}$-producing Xanthomonas-like isolates from biofilters as Stenotrophomonas nitritireducens sp. nov., Luteimonas mephitis gen. nov., sp. nov. and Pseudoxanthomonas broegbernensis gen. nov., sp. nov. Int J Syst Evol Microbiol 50, 273-282.

Gomori, G. (1955). Preparation of buffers for use in enzyme studies. Methods Enzymol 1, 138-146.

Harada, R. M., Campbell, S. \& Li, Q. X. (2006). Pseudoxanthomonas kalamensis sp. nov., a novel gammaproteobacterium isolated from Johnston Atoll, North Pacific Ocean. Int J Syst Evol Microbiol 56, 1103-1107.

Jeon, C. O., Park, W., Ghiorse, W. C. \& Madsen, E. L. (2004). Polaromonas naphthalenivorans sp. nov., a naphthalene-degrading bacterium from naphthalene-contaminated sediment. Int J Syst Evol Microbiol 54, 93-97.

Kimura, M. (1980). A simple method for estimating evolutionary rates of base substitutions through comparative studies of nucleotide sequences. J Mol Evol 16, 111-120.

Komagata, K. \& Suzuki, K. (1987). Lipid and cell-wall analysis in bacterial systematics. Methods Microbiol 19, 161-207.

Lane, D. J. (1991). 16S/23S rRNA sequencing. In Nucleic Acid Techniques in Bacterial Systematics, pp. 115-175. Edited by E. Stackebrandt \& M. Goodfellow. Chichester: Wiley.
Lányí, B. (1987). Classical and rapid identification methods for medically important bacteria. Methods Microbiol 19, 1-67.

Leifson, E. (1963). Determination of carbohydrate metabolism of marine bacteria. J Bacteriol 85, 1183-1184.

Rosselló-Mora, R. \& Amann, R. (2001). The species concept for prokaryotes. FEMS Microbiol Rev 25, 39-67.

Smibert, R. M. \& Krieg, N. R. (1994). Phenotypic characterization. In Methods for General and Molecular Bacteriology, pp. 607-654. Edited by P. Gerhardt, R. G. E. Murray, W. A. Wood \& N. R. Krieg. Washington, DC: American Society for Microbiology.

Stanier, R. Y., Palleroni, N. J. \& Doudoroff, M. (1966). The aerobic pseudomonads: a taxonomic study. J Gen Microbiol 43, 159-271.

Tamaoka, J. \& Komagata, K. (1984). Determination of DNA base composition by reversed-phase high-performance liquid chromatography. FEMS Microbiol Lett 25, 125-128.

Thierry, S., Macarie, H., lizuka, T., Geißdörfer, W., Assih, E. A., Spanevello, M., Verhe, F., Thomas, P., Fudou, R. \& other authors (2004). Pseudoxanthomonas mexicana sp. nov. and Pseudoxanthomonas japonensis sp. nov., isolated from diverse environments, and emended descriptions of the genus Pseudoxanthomonas Finkmann et al. 2000 and of its type species. Int J Syst Evol Microbiol 54, 2245-2255.

Thompson, J. D., Higgins, D. G. \& Gibson, T. J. (1994). CLUSTAL W: improving the sensitivity of progressive multiple sequence alignment through sequence weighting, position-specific gap penalties and weight matrix choice. Nucleic Acids Res 22, 4673-4680.

Wayne, L. G., Brenner, D. J., Colwell, R. R., Grimont, P. A. D., Kandler, O., Krichevsky, M. I., Moore, L. H., Moore, W. E. C., Murray, R. G. E. \& other authors (1987). International Committee on Systematic Bacteriology. Report of the ad hoc committee on reconciliation of approaches to bacterial systematics. Int J Syst Bacteriol 37, 463-464.

Weon, H. Y., Kim, B. Y., Kim, J. S., Lee, S. Y., Cho, Y. H., Go, S. J., Hong, S. B., Im, W. T. \& Kwon, S. W. (2006). Pseudoxanthomonas suwonensis sp. nov., isolated from cotton waste composts. Int J Syst Evol Microbiol 56, 659-662.

Yang, D.-C., Im, W.-T., Kim, M. K. \& Lee, S.-T. (2005). Pseudoxanthomonas koreensis sp. nov. and Pseudoxanthomonas daejeonensis sp. nov. Int J Syst Evol Microbiol 55, 787-791.

Yoo, S.-H., Weon, H.-Y., Kim, B.-Y., Kim, J.-H., Baek, Y.-K., Kwon, S.-W., Go, S.-J. \& Stackebrandt, E. (2007). Pseudoxanthomonas yeongjuensis sp. nov., isolated from soil cultivated with Korean ginseng. Int J Syst Evol Microbiol 57, 646-649.

Yoon, J. H., Kang, S. J., Oh, H. W. \& Oh, T. K. (2006). Stenotrophomonas dokdonensis sp. nov., isolated from soil. Int J Syst Evol Microbiol 56, 1363-1367.

Young, C. C., Ho, M.-J., Arun, A. B., Chen, W.-M., Lai, W.-A., Shen, F.-T., Rekha, P. D. \& Yassin, A. F. (2007). Pseudoxanthomonas spadix sp. nov., isolated from oil-contaminated soil. Int J Syst Evol Microbiol 57, 1823-1827. 